\title{
Emotional Intelligence as a Leadership Skill at University Level in Pakistan
}

\author{
Dr. Fakhra Aziz ${ }^{1}$
}

\begin{abstract}
Emotional intelligence leadership skills are necessary for effective and successful leadership. In today's innovative and demanding era, leadership plays a vital role in the success of any organization and emotional intelligence and leadership skills are key traits for successful Heads of departments because they have to handle the problems related to department, teachers and other staff. In Pakistan, education sector is under crises due to quality issue. In this context, this descriptive study attempts to measure and compare the emotional intelligence as leadership skill of heads in universities which leads to improving quality administration. Sample of 100 university heads is selected by purposive sampling technique. Among them 50 heads were men and 50 heads were women. A questionnaire Emotional intelligence scale for Leaders (EISL) was designed, aiming to measure and compare emotional intelligence leadership skills of male and female Heads at university level. Data was analyzed by using SPSS 17.00 version. In bivariate analysis association of each attribute category is tested with other attribute by using Pearson chi-square test at 5\% level of significance. Kendall's Tau is computed to measure the strength of significance of association of the ordinal categorical attributes. Mann-Whitney test was used to test the equality of the average ranks of responses between male and female heads. It is concluded that all heads of departments have significant level of emotional intelligence and further men have comparatively more emotional intelligence than womem.
\end{abstract}

Keywords: Emotional intelligence, leadership, leadership skills

\section{Introduction}

Emotional Intelligence (EI) is the skill of a leader which makes him/her a perfect leader. Generally, a "perfect leader," is the one who never lets his/her temper and emotions uncontrolled under crises or unfavorable conditions, who trusts his or her staff completely, always speaks softly, subordinates find it easy to talk to him and who always makes careful, informed decisions. These qualities show that someone has a high degree of emotional intelligence. Emotional intelligence is not restricted to only one's personal qualities but it is the ability to understand and manage emotions, and feelings of the people around him/her. Emotionally intelligent people usually know their own mind-set, inclination of their approach, and how their feelings and actions can affect others. For all leaders, especially in educational institutes, emotional intelligence is essential for their success because they have to manage institutional crises and deal with subordinates and students having different temper at different levels, categories and cultures. In Pakistan, economical, social and political situations have been deeply influenced the life of a coman man. Particularly the terrorism and law and order condition along with economical pressure are leading towards stress, depression and disturbance in the society. In this situation, the role of heads as a leader has become more important for they have not only to control their own emotions but to direct the emotions of others too.

\footnotetext{
${ }^{1}$ Jawed Ahmed Qureshi is visiting faculty at SZABIST, Karachi, jawedkhanqureshi@gmail.com ${ }^{2}$ Dr. Amanat Ali Jalbani is Professor and Vice President (Academics), SZABIST, Karachi, jalbani@szabist.edu.pk \begin{tabular}{llll|l}
\hline JISR-MSSE & Volume 12 & Number 1 & January-June 2014 & 1
\end{tabular}
} 
According to Boyatzis, Goleman and Rhee (2000) the regularity with which people show or use their competencies, directs ways in which they deal with themselves, their lives, job and others. In Pakistani universities, people from different ethnic, regional, religious and political backgrounds are involved in teaching, learning and other activities. A competition for survival has been observed there. Theory of natural selection cannot be applied on human society. There is a dire need to handle the diverse mindsets and situations which is only possible by emotionally intelligent leadership.

Emotional intelligence influences a leader's skills to be effective. Goleman (1998) says that leaders who do not expand their emotional intelligence have difficulty in developing better relationships with others. Performance of employees is significantly influenced by leadership skills. Sucess of our universities like other institutes largely depend on performance of employees. Since last few decades, performance and progress of universities are under debate.In this scenerio the present study aimed at examining emotional intelligence of Head of departments at university level in Pakistan. The research attempts to fulfill the need to comprehend gender differences in emotionally intelligent leadership. The prime focus is to examine the emotional intelligence and the role that gender plays in leadership.

\section{Hence the objectives are:}

- To examine the emotional intelligence of leadership at university level in Pakistan

- To compare the emotional intelligence of male and female leadership at university level in Pakistan

\subsection{Hypotheses}

- The four attributies of emotional intelligence are not associated with each other.

- Genders have no impact on emotional intelligence of leaders.

- Leaders (HOD's/ directors/deans etc) at university level possess a significant level of emotional intelligence.

\section{Literature Review}

Emotional intelligence has become a significent research area in leadership studies being required in various leadership issues like leadership style, leadership success, effective leader progress and transformational leadership. Goleman (1998) presented five well-known essentials of emotional intelligence:-

1. Self-awareness

2. Self-regulation

3. Motivation

4. Empathy

5. Social skills

A leader, who manages these attributes more skillfully, must have a higher level of emotional intelligence. Affective and successful leadership emerges from contingency theory and EI. Harber (2006) opines that factors like awareness of situation, personality, and others provide 
the base for development of model for emotionally intelligent leadership. Many theoretical studies were found in the area to explore this relationship. The central role of moods and emotions in the leadership process and contribution of EI in effective leadership are explained by George in 2000. He identifix that five essential elements of leader effectiveness are influenced by EI which are: development of cooperative goals and objectives; instilling in staff a positive reception of the importance of job behavior; enhancing passion, confidence, hopefulness, collaboration, and trust; cheering litheness in judgment and adjustment; and developing a significant affective personality for an institute.

Prati (2003) considers the EI a direly essential competency for successful headship and team performance in institutes. He takes EI in social context as the ability to read and know others, to understand the emotional reactions and to employ such understanding to direct others by emotional regulation and power. In the same year, Dulewicz and Higgs came on agreement with Goleman that EI is more important for one's success.

On the other hand, empirical research studies have also been conducted to explore and analyze this relationship. Barling, Slater, and Kelloway (2000) designed a study to examine the relationship between EI and transformational leadership while Palmer (2001) studied the relationship between EI and effective leadership. Higgs and Aitken (2003) pointed out a significant association between EI and leadership. Afzal ur Rahim and Psenicka (2005) found empathy as a liaison of the relationship between emotional intelligence and effective leader. Rosete and Ciarrochi (2005) concluded that heads having higher EI are more successful in achieving goals and are reputed effective heads among their subordinates. Relationship between leaders and subordinates has been considered as emotional one. Workers, affective job performance can be achieved when they have trust in their leadership, motivated and satisfied under specific working environment. George (2000) pointed out the consequences of this emotional relationship between leaders and followers and said that emotional intelligence of leaders leads to enhance the job performance and effectiveness of followers at all levels of organization.

A report published by Center for Creative Leadership (2003) narrated higher levels of EI is coupled with enhanced performance in following categories: sharing management, providing healthy working environment to followers, self responsiveness, balance between personal life and work, openness and self-control, developing new relationships and and restoration of previous one, determination, authority, facing and handling problem subordinate, adjust management, etc. Srivastva and Bharamanaikar (2004) examined the relationship of emotional intelligence with leadership excellence, success and job satisfaction. They concluded that emotional intelligence significantly correlates with transformational leadership and success. Punia (2005) found after analyzing the data of 250 executives that leaders having higher emotional intelligence consider changes as opportunities for improvement, and they value not constancy but ongoing growth of individual workers and of the institute itself. Rosete and Ciarrochi (2005) recognized a relationship between emotional intelligence and leadership effectiveness. By their results it is revealed that leaders with higher emotional intelligence are more likely to get organizational outcomes and their subordinates consider them as effective leaders. Alon and Higgins (2005) opined that with the growing rate of globalization, both emotional and cultural intelligence has become important for cross-cultural leaders to do extremely well. International leaders can maximize success by best use of their emotional intelligence.

\begin{tabular}{lll|l}
\hline JISR-MSSE & Volume 12 & Number 1 & January-June 2014
\end{tabular}


Rego, Sousa, Cunha, Correia, and Saur (2007) took a sample of 138 top and middle managers from 66 organizations and data collected was analyzed. They examined the relationship between leaders emotional intelligence and creativity of their teams. Emotional intelligence was measured by a self-report scale consisting of following dimensions: understanding one's emotions, self-control against criticism, use of emotions, regulation of emotions, empathy and emotional contagion, understanding other people's emotions. They reported that emotionally intelligent leaders act in ways that accelerate the creativity of their teams.

Singh (2007) examined the relationship between emotional intelligence and leadership effectiveness.Emotional intelligence was found to be positively and significantly related to organizational leadership for males and females. The results exposed no significant differences between male and female heads in terms of emotional intelligence and in general successful leadership. The most important predictor of leadership reported was management aspect of emotional intelligence. The study suggested that for becoming effective leaders, they should have to develop their relationship skills.

Gender specific viewpoint was adopted in many theoretical and empirical researches for exploring gender differences in working environment as well as observing their EI. Gender differences present in how male and female perceive and provide leadership. Haber and Komives (2009); Dugan, Komives and Segar (2008), and Eagly and Carli (2007) conducted researches on leadership styles and attributes in perspective of gender. They all agreed that females implement more social, consulting, and transformational approaches to leadership than males. Gender differences are indicated by Leadership behavior, leadership styles, and overall perspectives of leadership. Male and female are not same in personality characteristics that are significant indicators of leadership (Eagly \& Carli, 2007; Judge, Bono, Ilies, \& Gerhardt, 2002). Female's personality characteristics depicts friendliness, tenderness, encouraging emotions, extraversion, and sincerity to thoughts, while male's personality characteristics show boldness (Costa, Terracciano, \& McCrae, 2001; Eagly \& Carli, 2007). Eagly and Carli (2007) reported gender difference in leadership style as female do more democratic leadership while male practice more autocratic leadership. They further concluded that female's leadership styles are dependent on the environment and the specific position for which they are performing their job. In male-dominated institutions, female may exhibit autocratic leadership.

Dugan and Komives (2007) identified during their study that women exhibit lower leadership self-efficacy, or confidence to lead, than men. Earlier Kezar and Moriarty's (2000) research presented the similar findings as they found lower levels of leadership self-efficacy among women. Brackett, Rivers, and Shiffman (2006) said that emotional intelligence of male and female has been measured by their ability to recognize, employ, appreciate and control emotions. Guastello and Guastello (2003) reported contradictory results for young people. They conducted research to examine the impact of age on gender difference regarding their emotional intelligence. Considerable difference in male and female's emotional intelligence was noted for peoples having age of late forties, with females rating higher than males while no gender differences present for the people having less age. The researches already conducted in the area reported that men are less inclined to give importance to others in their leadership approach as well as display self strengths less than women. Females prefer the social dynamics of leadership, mainly working in a collaborative way. 
Higher intrapersonal skills exist in women than men. Elias, Arnold and Hussey (2003) measured intelligence to the unprocessed facts and emotions to the ability of practical use of this knowledge. They suggested that effective leadership is a blend of traditional intelligence and emotional intelligence. Earlier Dyer (2001) opined that successful leaders are those who have a strong set of interpersonal skills and behave according to the situation. Mandell and Pherwani (2003) conducted a study to explore the relationship between emotional intelligence and transformational leadership style and the gender differences within each variable. They further studied the relationship between gender and emotional intelligence. They reported emotional intelligence as a significant predictor of transformational leadership . Leaders who own positive transformational leadership traits can be identified by their emotional intelligence. Later on Webb (2004) conducted a study to examine the extent to which emotional intelligence is related to transformational leadership within mentoring relationships. He reported that several aspects of transformational leadership like chrisma and motivation can be predicted by emotional intelligence.

Kaneez (2006) reported a significant difference between male and female on five subscales of emotional intelligence namely Assertiveness, Independence, Stress Tolerance and Impulse Control. Her data analysis showed that males exhibit more assertiveness, self- recognition about himself, show more autonomy and administration in accordance with the situations than the females. She opined that one of the reasons for higher independence and impulsive assertiveness in males is that in Pakistani society male ratio is high.

In short, review of literature in the area suggests that female leaders try to value others as well as exhibit intrapersonal strengths more than male leaders. They demonstrate a preference for working with followers in a collaborative way. While males' self-reported self-efficacy in their leadership abilities was higher than females.

\section{Methodology}

This cross sectional study is descriptive in nature and designed to examine and compare the Emotional Intelligence of male and female heads in universities. The target population of the study was all the HoD's/Deans/Directors working in the Chartered universities located in the province Punjab. There are 20 universities chartered by the Government of Punjab and 24 are chartered by the Government of Pakistan among them five are in Punjab. Total population consists of 25 chartered universities in Punjab. By purposive sampling method 3 universities from Lahore and tow from Rawalpindi were selected. By using same approach, 20 heads of department were selected from each university to collect data. Total sample consisted of 100 HoDs. Among them 50 were male and 50 were female. In order to make complete and comprehensive analysis of the collected data, the descriptive analysis including the frequencies and percentages of each and every factor/attribute of Emotional Intelligence were calculated and also found out a comparative relationship of Emotional Intelligence level of male and female heads. Analytical section is based on the independent sample t-test, chi-square test of independence and Mann-Whitney test for the equality of mean ranks. 
Table 1 Population of the Study

\begin{tabular}{|lll|}
\hline $\begin{array}{l}\text { Universities chartered } \\
\text { Punjab Government }\end{array}$ & by $\begin{array}{l}\text { Universities chartered by } \\
\text { Federal Government in Punjab }\end{array}$ & Total \\
20 & 5 & 25 \\
\hline
\end{tabular}

Table 2 Sample Characteristics

\begin{tabular}{|llll|}
\hline Sr. No. & Universities & Male HoDs & Female HoDs \\
\hline 1 & Lahore College for Women University, Lahore & -------- & 20 \\
\hline 2 & University of the Punjab, Lahore & 10 & 10 \\
\hline 3 & University of Education, Lahore & 20 & \\
\hline 4 & Fatima Jinnah Women University, Rawalpindi & ------------- & 20 \\
\hline 5 & Pir Mehr Ali Shah Arid Agriculture, University Rawalpindi & 20 & --------- \\
\hline & Total & 50 & 50 \\
\hline
\end{tabular}

\subsection{Instrument}

A questionnaire (EISL) was designed by reviewing an extensive literature. It was consisted of almost all possible factors relating to Emotional Intelligence Leadership Skills. It includes two sections first one was related to demographics and second one was consist of statements related to emotional intelligence of leaders. Total of thirty five statements were categorized into following attributes of emotional intelligence. Self-awareness, Self-management, Social awareness and Relationship management. Heads were requested to response the statements on 5-point Likert scale.

Table 3 Category wise distribution of statements

\begin{tabular}{|lll|}
\hline Sr no & Categories & Statements \\
\hline 1 & Self-awareness & 9 \\
\hline 2 & Self-management & 8 \\
\hline 3 & Social awareness & 9 \\
\hline 4 & Relationship management & 9 \\
\hline
\end{tabular}

\subsection{Pilot Testing and Reliability of the Questionnaire}

To check the reliability of the instrument a pilot study was conducted. For this purpose 12 HoD's from the University of the Punjab and Lahore College for Women University were randomly selected. Among them six were male and six were female. It was to check the capability of the instrument for making necessary changes in it. Sample HODs were asked about the precision and configuration of the questionnaire. They found the statements to be simple and straightforward, so no major changes were required; only minor changes to the

\begin{tabular}{l|llll}
\hline 2 & January-June 2014 & Volume 12 & Number 1
\end{tabular}


wording of few statements were made. By using the Cronbach's alpha, the result of the reliability coefficient was found 0.742 . Face and content validity was confirmed by the experts in the area.

\section{Data Analysis}

All the statements were pre-coded for computer analysis and all the record were rechecked to ensure correct data entry. The data was proceed and entered by using SPSS version 17.0 for analyzing.

Data analysis is carried out in two parts as,

To measure

1. Mutual association of the four attributes of emotional intelligence

2. Gender difference

\subsection{Mutual association of the four attributes of emotional intelligence Bivariate Analysis with Chi-Square}

In bivariate analysis association of each attribute category is tested with other attribute by using Pearson Chi-Square test at 5\% level of significance. Kendall's Tau is computed to measure the strength of significance of association of the ordinal categorical attributes. For this purpose frequency response of each statement within an attribute category was measured. Then mean score of responses (agree and disagree) were calculated.

Table 4 Association Between Self Awareness and Self Management Attributes

\begin{tabular}{|c|c|c|c|c|c|c|}
\hline & & & \multicolumn{3}{|c|}{ Self management } & Total \\
\hline \multirow{3}{*}{ Self awareness } & \multirow{2}{*}{\multicolumn{2}{|c|}{ Agree }} & Agree & \multicolumn{2}{|c|}{ Disagree } & \\
\hline & & & 40 & \multicolumn{2}{|l|}{29} & 69 \\
\hline & \multicolumn{2}{|c|}{ Disagree } & 25 & \multicolumn{2}{|l|}{6} & 31 \\
\hline Total & \multicolumn{2}{|l|}{65} & 35 & \multicolumn{2}{|l|}{100} & \\
\hline \multicolumn{7}{|c|}{ Chi-Square Tests } \\
\hline & & Value & df & $\begin{array}{l}\text { Asymp. Sig. } \\
\text { (2-sided) }\end{array}$ & $\begin{array}{l}\text { Exact Sig. } \\
\text { (2-sided) }\end{array}$ & $\begin{array}{l}\text { Exact Sig. (1- } \\
\text { sided) }\end{array}$ \\
\hline \multicolumn{2}{|c|}{ Pearson Chi-Square } & $4.834^{\mathrm{a}}$ & 1 & .028 & & \\
\hline \multicolumn{2}{|c|}{ Continuity Correction $^{b}$} & 3.889 & 1 & .049 & & \\
\hline \multicolumn{2}{|c|}{ Likelihood Ratio } & 5.134 & 1 & .023 & & \\
\hline \multicolumn{2}{|c|}{ Fisher's Exact Test } & & & & .041 & .022 \\
\hline \multicolumn{2}{|c|}{ Linear-by-Linear Association } & 4.785 & 1 & .029 & & \\
\hline \multicolumn{2}{|c|}{$\mathrm{N}$ of Valid Cases } & 100 & & & & \\
\hline
\end{tabular}

a. 0 cells $(.0 \%)$ have expected count less than 5 . The minimum expected count is 10.85 .

b. Computed only for a $2 \times 2$ table 


\section{Symmetric Measures}

\begin{tabular}{|llllll|}
\hline & & Value & $\begin{array}{l}\text { Asymp. Std. } \\
\text { Error }^{\mathrm{a}}\end{array}$ & Approx. $\mathrm{T}^{\mathrm{b}}$ & Approx. Sig. \\
\hline Ordinal by & Kendall's tau-b & -.220 & .089 & -2.402 & .016 \\
Ordinal & Kendall's tau-c & -.194 & .081 & -2.402 & .016 \\
& Gamma & -.503 & .193 & -2.402 & .016 \\
\hline
\end{tabular}

p-value of the chi-square was found less than the significance level that was set to be $5 \%(0.028<0.05)$ which indicated a significant association between both attributes.

'The Kendall's Tau-b is -0.220 which also shows a moderate level of association between both categories.

Table 5 Association between Social awareness and Relationship management attributes

\begin{tabular}{|lllll|}
\hline & \multicolumn{4}{c|}{ Relationship management } \\
\hline & & Agree & Disagree & Total \\
\hline Social awareness & Agree & 39 & 30 & 69 \\
& Disagree & 28 & 3 & 31 \\
Total & 67 & 33 & 100 & \\
\hline
\end{tabular}

\section{Chi-Square Tests}

\begin{tabular}{|llllll|}
\hline & Value & df & $\begin{array}{l}\text { Asymp. Sig. } \\
(2-s i d e d)\end{array}$ & $\begin{array}{l}\text { Exact Sig. } \\
\text { (2-sided) }\end{array}$ & $\begin{array}{l}\text { Exact Sig. (1- } \\
\text { sided) }\end{array}$ \\
\hline Pearson Chi-Square & $11.053^{\mathrm{a}}$ & 1 & .001 & \\
Continuity Correction & & & & \\
Likelihood Ratio & 9.577 & 1 & .002 & .001 & .001 \\
Fisher's Exact Test & 12.647 & 1 & .000 & \\
Linear-by-Linear Association & 10.942 & 1 & .001 & & \\
N of Valid Cases & 100 & & & & \\
\hline
\end{tabular}

a. 0 cells $(.0 \%)$ have expected count less than 5 . The minimum expected count is 10.23 .

b. Computed only for a $2 \times 2$ table

\section{Symmetric Measures}

\begin{tabular}{|c|c|c|c|c|c|}
\hline & & Value & $\begin{array}{l}\text { Asymp. Std. } \\
\text { Error }^{\mathrm{a}}\end{array}$ & Approx. $\mathrm{T}^{\mathrm{b}}$ & Approx. Sig. \\
\hline Ordinal by & Kendall's tau-b & -.332 & .076 & -3.997 & .000 \\
\hline \multicolumn{6}{|l|}{ Ordinal } \\
\hline & Kendall's tau-c & -.289 & .072 & -3.997 & .000 \\
\hline & Gamma & -.755 & .140 & -3.997 & .000 \\
\hline \multicolumn{2}{|c|}{$\mathrm{N}$ of Valid Cases } & 100 & & & \\
\hline
\end{tabular}

a. Not assuming the null hypothesis.

b. Using the asymptotic standard error assuming the null hypothesis.

\begin{tabular}{l|llll}
\hline 2 & January-June 2014 & Volume 12 & Number 1 & JISR-MSSE
\end{tabular}


Social awareness' and 'Relationship management' attributes are found to be significantly associated as p-value of the chi-square is less than the significance level that is set to be $5 \%$ $(0.001<0.05)$. The Kendall's Tau-b is -0.332 which shows a moderate level of association between the two ordinal categories. The statements related to above four attributes were found to be associated. So it is concluded that these four attributes were highly significant in the emotional intelligence leadership skills.

\subsection{Emotional Intelligence of Male and Female Leaders}

\subsubsection{Mann-Whitney Tests for the Ordinal Data}

The Mann-Whitney test is a nonparametric equivalent of the independent samples $t$ test. A nonparametric test is used when the assumptions of the $t$ test are not met. The $t$ test requires the samples to come from normally distributed populations, with equal variances in both groups. The most common use of the Mann-Whitney test is when the data are ordinal. Following table showing the comparison of average response between the both genders.

Table 6 Comparison of EmotionalIntelligence Level of Male and Female HoDs

\begin{tabular}{|lllll|}
\hline SrNo & Attributes & \multicolumn{2}{l|}{ Mean Ranks } & P-Value \\
\hline & & Male & Female & \\
\hline 1 & Self-awareness & 55.64 & 45.47 & 0.028 \\
\hline 2 & Self-management & 61.23 & 39.92 & 0.000 \\
\hline 3 & Social awareness & 50.375 & 50.625 & 0.0295 \\
\hline 4 & Relationship management & 55.21 & 43.11 & 0.019 \\
\hline & Overall Emotional intelligence score & 55.61 & 44.78 & 0.018 \\
\hline
\end{tabular}

All the four attributes of the Emotional Intelligence given above are found to be significant using Mann-Whitney test, which is used to test the equality of the average ranks of responses between male and female heads. As p-value of the Mann-Whitney test is smaller than the significance level $\mathrm{p}<0.05$, so null hypothesis "Genders have no impact on emotional intelligence of leaders" is rejected and is concluded that average ranks of responses between the both genders are significantly different.

Within above categories, statements related to "self control", "Keep a personal journal", "tolerance", "having a code of ethics", "taking self responsibility", proud of being head", "job satisfaction", professional competence" and teamwork were responded by male and female heads significantly different.

\section{Discussion}

The present study provides awareness about emotional intelligence, association of attributes of emotional intelligence and reports a significant difference between emotional intelligence of male and female heads at university level.

Wren (2005) says that leadership consider the working with and through staff leads towards the achievement of institutional goal. Relationship between leaders and subordinates is very

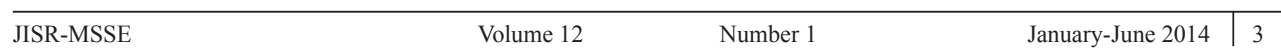


important for the success of any organization. Emotional intelligence leadership skills are required to develop and maintain a positive relationship. The present study reports presence of significant emotional intelligence in heads of departments at university level. It is an encouraging situation in the present scenario when all are trying to raise the standards of universities. Although many research studies conducted in the area reported a close relationship between emotional intelligence and leadership style but leadership style was not in the scope of present study. It focused on the presence of significant level of emotional intelligence, mutual association of attributes of emotional intelligence and to compare the emotional intelligence leadership skill of male and female heads. The results of the study do not support the Mendel and Pherwani's study who in 2003 examined the extrapolative association between emotional intelligence and transformational leadership style, the gender differences within a catagory, and relationship between gender and emotional intelligence. In the light of their findings, Gender did not anticipate a transformational leadership style over and above emotional intelligence. The present study concludes that 'Social awareness' and 'Relationship Management' attributes are significantly associated. These results are in agreement with Abraham (2000) who deliberated that the social skills component of Emotional. Intelligence is related to positive interpersonal relationships and it increases the feeling of job satisfaction and decreases occupational stress. Contrary to present study Groves (2005) reported that Female leaders have higher social and emotional skills than male.

On the other side,findings of Neubert and Taggar (2004) are in line with the results of present study to some extent as they opined When men carry out expectations that a leader be conscientiousness and emotionally stable, they appear as informal leaders more than women who complete the same expectations, because these attributes are expected more in women. Findings of studies reported by King (1999), Sutarso (1999), Wing and Love (2001) and Singh (2002) showed that males have lower emotional intelligence than that of females which are contrary to the results of present study.

The report presented by Kaneez (2006) established that there is a significant difference between male and female on some subscales of emotional intelligence. The results indicated that there is a significant difference between the mean scores of both genders. Women show more assertiveness, self recognition about herself while men show more independence and management according to the situations than the women. Recently Islam, Arif and Tahira (2011) concluded that female heads are more emotionally intelligent than male heads which is contrary to the findings of present study. Before them, in 2009, Ahmad, Bangash and Khan conducted a study to investigate the Emotional intelligence among male and female. They reported that Males have high emotional intelligence as compare to females which support the present study.

After an extensive review, it is clear that emotional intelligence leadership skill is not gender specific. They have or they have not but it is impossible to decide that which gender possess more. It may be influenced by culture, society, opportunities and other related variables. 


\section{Findings}

1. Data analysis shows that Heads of department at university level possess significant level of emotional intelligence.

2. It is concluded that 'social awareness' and 'relationship management' attributes are found to be significantly associated.

3. A similar significant association is revealed between self-awareness' and 'self management' attributes by data analysis.

4. It is found that male and female heads have significant difference in their emotional intelligence level.

\section{Recommendations}

Every educational leader dreams for the success of institute, for this his/her own emotional intelligence leadership skills play a vital role among other influential factors. No doubt, change provokes emotions and often that are unpleasant. Successful leaders should realize that emotional intelligence can be developed (Moore, 2009). Training workshops for the development of emotional intelligence leadership skills should be conducted.

It is of great importance for leaders /Heads to analyze their own emotional intelligence because effective leadership is positively influenced by not only developing but maintaining it too. Further research should be conducted to investigate the impact of emotional Intelligence of leaders on the performance, stress level, professional commitment and other related variables /attributes of their sub-ordinates.

\section{References}

Abraham, R. (1999), Emotional intelligence in organizations: a conceptualization. Genetic, Social, and General Psychology Monographs, 125(2), 209.

Ahmad, S., Bangash, H., \& Khan, S. A. (2009). Emotional intelligence and gender differences. Sarhad Journal of Agriculture. 25(1), 127-130.

Bain, O. \& Cummings, W. (2000). Academe's glass ceiling: societal, professional-organizational, and institutional barriers to the career advancement of academic women. Comparative Education Review, 44(4),493-514.

Bar-On, R., (2000). Emotional and social intelligence: Insights from the Emotional Quotient Inventory. In R. Bar-On \& J. D. A. Parker (Eds.), The Handbook of Emotional Intelligence (pp. 363-388). San Francisco: Jossey-Bass.

Bell Edmondson, E. L. J. \& Nkomo, S. M. (2003). Our separate ways: barriers to advancement. In Ely, R. J. Foldy, E.G. \& Scully, M. A. (Eds.), Reader in Gender, Work and Organization (pp. 343-361). Maldem, M.A.: Blackwell Publishing. 
Bernstein, A. R (1984). Foundation support for administrative advancement: A mixed record, in Tinsley, A. Secor, C. \& Kaplan, S. (Eds.), Women in Higher Education Administration (pp. 77-84). San Francisco:Jossey Bass.

Blackmore, J. (2002). Globalisation and the restructuring of higher education for new knowledge economies: new dangers or old habits troubling gender equity work in universities? Higher Education Quarterly, 56(4), 419-441.

Blackmore, J. (2002). Troubling women: The upsides and downsides of leadership and the new managerialism, in Reynolds, C. (Ed.) Women and School Leadership-International Perspectives. Albany: State university of New York, 49-69.

Borg, W. R. \& Gall, M. D. (1989). Educational Research. An introduction: Fifth edition. New York: Longman.

Brown, H. ( 1997). Equal Opportunities policy. In Eggins, H. (Ed.) Women as Leaders and Managers in Higher Education. Buckingham: Bristol. P. A. 109-121.

Carless, S. (1998). Gender differences in transformational leadership: An examination of superior, leader, and subordinate perspectives. Sex Roles, 39 (11-12), 887-902.

Cates, W. M. (1985). A practical Guide to Educational Research. New Jersey: Prentice Hall.

Center for Creative Leadership. (2003.) Leadership skills and emotional intelligence. Center for Creative Leadership.

Cherniss, C., Goleman, D., Emmerling, R., Cowan, K. \& Adler, M. (1998). Bringing emotional intelligence to the workplace. A technical report issued by the Consortium for Research on Emotional Intelligence in Organizations. Pertained from http://www.eiconsortium.org/research/technical_report.htm

Furnham, A. (1994). Personality at Work. London: Routledge.

Collard, J.L. (2001). Leadership and gender: An Australian perspective. BEMAS, 29(3), 343345.

Cross, S. \& Madson, L. (1997). Models of the self: Self-construals and gender. Psychological Bulletin, 122, 5-37.

Cummings, N.P. (1979). Women in higher education administration. In Berry M.C. (Ed.) Women in Educational Administration: A book of readings, 63-69 SI: National association for women deans.

Daft, R. L. (2005). The Leadership Experience. Third edition. Ohio: Mason,

Daniel, E. D. (1997). African American nursing administrators in the academy - breaking the glass ceiling. In Benjamin, L. (Ed.) Black women in the Academy-Promises and Perils. Gainesville: University Press of Florida, 168-178. 
Dopson, S. \& McNay, I. (1996). Organizational culture. In Warner, D. \& Palsreyman, D. Higher education management: the key elements. Bristol P.A.: Society for research into Higher Education \& Open University Press, 17-32

Drodge, E. N., \& Murphy, S. A. (2002), Interrogating Emotions in Police Leadership. Human Resource Development Review, 1 (4), 420-438.

Duckelt, E. and M. Raffalli. (1989). Taking care, maintaining the self and the home in adolescents. J. Youth and Adolescence. 18(6), 549.

Dulewicz, V and Higgs, M J (2003b), "Leadership at the top: the need for emotional intelligence", International Journal of Organisational Analysis, 11(3)

Dunn, P. (2002). The impact of starting a new venture on the entrepreneur and their family: Expectations, reality, and willingness to start again. Presented at the Association for Small Business and Entrepreneurship 2002 Annual Conf.

Eagly, A. H. \& Johnson, B. T. (1996). Gender and leadership style: A meta analysis: Sixth edition, in Steers, R .et al: Motivation and Leadership at work. York: McGraw-Hill, 315-345.

Eagly, A.H. \& Johnson, B.T. (1990). Gender and leadership style: A meta-analysis. Psychological Bulletin, 108(2), 233-256.

Eagly, A.H., Karau, S.J., \& Makhijani, M.G. (1995). Gender and the effectiveness of leaders: A meta-analysis. Psychological Bulletin, 117(1), 125-145.

Eagly, A.H., Makhijani, M.G. \& Klonsky, B.G. (1992). Gender and the evaluation of leaders: A meta-analysis. Psychological Bulletin, 111(1), 3-22.

Engwall, L. Levay, C. \& Lidman, R. (1999). The roles of university college rectors. Higher education management, 11(2):75-91 Fine, M.G.2003. Building successful multicultural organizations: challenges and opportunities, in Ely, R.J. Foldy, E.G. \& Scully, M.A. (eds.) Reader in gender, work and organization. Maldem, M.A.: Blackwell Publishing, 308-317.

Forster, N. (2001). A case study of women academics' views on equal opportunities, career prospects and work-family conflicts in a UK university. Career Development International 6(1),28-3.

Gmelch, W.H. \& Miskin, V.D. (1993). Leadership Skills for Department Chairs. Boston: Anker Publishing.

Goleman, D. (1998). Working With Emotional Intelligence. New York: Bantam.

Green, P. S. ( 1997). Rites of passage and Rights of way- a woman administrator's experiences, in Benjamin, L. (ed.) Black Women in the academy promises and perils. Gainesville: University Press of Florida, 146-147. 
Goleman, D. (1998). What Makes A Leader? Harvard Business Review. November-December.

Greyvenstein, L. A. (1989). The development of women for management positions in education. Doctoral dissertation, Potchefstroomse Universiteit vir Christelike Hoer Onderwys, Potchefstroom.

Greyvenstein, L. A.( 2000). The untapped human resource? An overview of women in educational management in South Africa. South African Journal of Education, 20(1):3033.

Gupton, S. L., \& Slick, G.A. (1996). Highly successful women administrators: the inside stories of how they got there. Thousand Oaks: Corwin Press.

Hall, V. (2002). Reinterpreting entrepreneurship in education: A gender perspective. In C. Reynolds (Ed.), Women and School Leadership -International Perspectives (pp. 1328). Albany: State University of New York.

Halvorsen, E. (2002). Gender audit. In G. Howie \& A. Tauchert, (Eds.), Gender, Teaching and Research in Higher Education: Challenges for the 21st Century (pp. 9-19). Hampshire: Ashgate.

Harman, G. (2002). Academic leaders or corporate managers: deans and heads in Australian higher education, 1977 to 1997. Higher education management and policy, 14(2), 53 69.

Higgs, M., \& Aitken, P. (2003). An exploration of the relationship between emotional intelligence and leadership potential. Journal of Managerial Psychology, 18(7/8), 814823.

Kaneez, U. (2006). Emotional intelligence among the individual with depression and without depression. A comparative study. Unpublished M.Sc. Dissertation. National Institute of Psychololgy, Quaid-e-Azam University, Islamabad.

Landau, J. (1995). The relationship of race and gender to managers' ratings of promotion potential. Journal of Organizational Behavior, 16 (4), 391-400.

Moore, B. (2009), Inspire, Motivate, Collaborate: Leading with Emotional Intelligence. Westerville, Ohio: National Middle School Association.

Osborn, R.N. \& Vicars, W. M. (1976). Sex stereotypes: An artifact in Leaders Behavior and Subordinate Satisfaction Analysis? Academy of Management Journal, 439-449.

Petrides, K. V., \& A. Furnham. (2001). Trait emotional intelligence: Psychometric investigation with reference to established trait taxonomies. Europ. J. of Personality, $15,425-448$

Prati, L. M., Douglas, C, Ferris, G. R., Ammeter, A. P., \& Buckley, M. R. (2003a). Emotional intelligence, leadership effectiveness, and team outcomes. The International 
Journal of Organizational Analysis, 11, 21-30

Ragins, B. (1991). Gender effects in subordinate evaluations of leaders: Real or artifact? Journal of Organizational Behavior, 12(3), 259-268.

Richard. B. ( 2010). He Relationship Between Emotional Intelligence And Effective Leadership of Headteachers in Selected Secondary Schools of Rubaga South, Kampala District A Dissertation Sub Mitted In Partial Fulfillment Of The Requirement For The Award Of The Degree Of Master Of Science In Human Resource Management of Makerere University, Kampala

Sandhu, P., \& Mehrotra, N. (1999). Time pattern of female students with special reference to leisure time activities. Indian Journal of Social Research. 40(4), 285-296.

Singh, D. (2002). Emotional Intelligence at Work: A Professional Guide. Sage Publications: New Delhi.

Sutarso, P. (1999). Gender differences on the emotional intelligence inventory (EQI). Dissert. Abst. Int.

Tapia, M. L. (1999). A study of the relationships of the emotional intelligence inventory (intelligence tests). Dissertation. Abst. Int.

Wren, D. A. (2005). The History of Management Thought. Hoboken, John Wiley \& Sons: New Jersey.

Zafr, U. I., Arif, M., \& Tahira, S. (2011). Leaders' Emotional Intelligence: Effective Leadership 